\title{
A Method for the Numerical Modelling of Embedded Rails and Determining Parameters to be Optimized
}

\author{
Z. Major \\ Széchenyi István University, Department of Transport Infrastructure \\ Egyetem tér 1, 9026 Győr, Hungary \\ Phone: +36 96503038 \\ e-mail: majorz@sze.hu
}

Abstract: To carry out FEM modelling two model parameters are needed the elastic (Young) modulus (E) and the Poisson-coefficient $(\mu)$. Unfortunately, they are not available in every case, and even if so, they need to be corrected. The author's earlier examinations have shown that FEM models are extremely sensitive to the value of the Poisson-coefficient. A very small change in them causes a significant difference in determining the elastic coefficient of the rail support. Literature deals with the factors determining the elastic characteristics of embedded rails. In practice the details for the spring constant on a given geometry test specimen (D) and Shore-A hardness (ShA) are available. These details can't be directly used to create the model but they are suitable to determine parameters that are close to the real values.

Keywords: embedded rail, material properties of pouring material, optimalisation of ERS

\section{Introduction}

Due to the increasing requirements for rail transport (noise and vibration load, duration costs), embedded rails are gaining more and more ground in our country. They are mainly applied on bridges, grade crossings, tunnels and light rails here. At the moment their practical planning is made with expensive laboratory examinations, examining each variant. Their optimization is genarally not an issue, although accurately selected parameters could lead to significant cost savings and the more punctual performance of the requirements for environmental load.

In this article the author presents the parameters for optimization and their effect on the behaviour of the structure. After that, I am going to introduce the numerical determination of the parameters through two case studies and make a comparison with 
the results of the real laboratory measurements. Detailed recommendations are found in connection with numerical modelling and laboratory examinations in Stefan Lehner's $\mathrm{PhD}$ dissertation [1] and in the author's earlier articles published in Sínek Világa [2, 3]

\section{Parameters that can be optimized with FEM modelling}

V.L. Markine. A.P. de Man, S. Jovanovic and C. Esveld describe the optimization of embedded rails for multi criteria in their article "Optimum design of embedded rail structure of high-speed lines [4]" and in C. Esveld's book Modern Railway Track [5). In the article such variants were examined that are unnecessary for practical planning because the variety of available materials and rails is given so their alteration is only possible for determined cases in the engineering practice.(For instance, there is no point in describing the change of thickness of rail foot as a function in the optimization process because these values are characteristic for only one rail system and even with the discovered optimum there will not be a new rail type developed considering the received values.) So the author summarized the characteristics to be optimized below.

- Elastic characteristics: Using properly selected embedding compound, punctually planned embedding sizes, if necessary with the help of elastic trips the bending moment in the rail, the vertical and lateral deformation of the rail under vehicle load, the security against opening gaps because of weld rupture/rail fracture and vertical thermal buckling can be influenced favourably. So during the process of optimization these conditions must be examined together.

- Rail system and rail quality: Due to homogenous, constant vertical and lateral stiffness the bending moment and deformation of the rail are more favourable than in ballasted tracks so it is possible to apply rails with lower inertia systems than in the case of traditional solutions.

- Quantity of embedding compound: the quantity of the embedding compound is not independent from the evolving spring constant, so optimization is only possible the two coefficients are examined together. Quantity is affected by the geometry of the selected rail system, the rail channel, the embedding, and the application of material saving items. Based on the known geometry the rate of the specific material consumption can be determined, which is nothing else but the quantity of the embedding compound referring to one rail running meter. The symbol for the parameter: $\mathrm{F}_{\mathrm{K}}\left[\mathrm{dm}^{3} / \mathrm{m}\right]$.

- Maintenance: On the basis of the maintenance requirements typical for the formed structure, an attempt can be made to determine a parameter describing the maintenance requirements, which takes the interference costs into consideration during the technical lifespan of the rail. It is symbolized with $F_{F}$ $[\mathrm{HUF} / \mathrm{m}]$. In this coefficient the needs can be enforced for rail servicing with 
different rail types and the favourable effect of the properly selected rail quality.

- Acoustic characteristics: By properly selecting the type of the embedding compound, reducing the free surface of the rail, tearing the vibration bridge more favourable noise and vibration characteristics can be obtained than in the case of traditional tracks. Natural frequency and the free surface are needed to know to make the acoustic qualifying number. There are guidelines for calculation it [4].

With the help of numerical modelling it became possible to model a high number of variations, which can save a significant part of long and expensive laboratory examinations. Using the results of FEM program examinations the optimum variant can be chosen. To achieve this, firstly, it is necessary to normalize each qualifying number, because their order of magnitude and dimension is different, as well. That's why the coefficient of each value is needed to make up with values typical for the initial variant. (A generally applied form that is typical of the given application area can be seen as the initial base, which has to be defined in advance.) After this, by ordering the appropriate sizes of weight to the normalized qualified numbers the variation has to be chosen, in the case of which the total of the weighed qualified numbers is minimal. So the laboratory examinations only have to be carried out on this form if the customer finds it necessary.

\section{Data available and necessary for finite element modelling}

To carry out FEM modelling two model parameters are needed the elastic (Young) modulus (E) and the Poisson-coefficient $(\mu)$. Unfortunately, they are not available in every case, and even if so, they need to be corrected. The author's earlier examinations have shown that FEM models are extremely sensitive to the value of the Poissoncoefficient. A very small change in them causes a significant difference in determining the elastic coefficient of the rail support. Literature [6] deals with the factors determining the elastic characteristics of embedded rails.

In practice the details for the spring constant on a given geometry test specimen (D) and Shore-A hardness $\left(\mathrm{Sh}_{\mathrm{A}}\right)$ are available. These details can't be directly used to create the model but they are suitable to determine parameters that are close to the real values.

\subsection{Determining the elastic module}

The value of the elastic modulus can approximately be determined according to the Shore-A hardness. Johannes Kunz and Mario Studer give a closed formula for it [7]. They made observations based on Boussinesq's elastic half space theory matching DIN EN ISO 868 [8], which regulates the geometry of the examination device and the other parameters of the examination. They determined the following relation between the elastic modulus and Shore-A hardness: 


$$
\mathrm{C}=\frac{1-\mu^{2}}{2 \cdot \mathrm{R} \cdot \mathrm{C}_{3}} \cdot \frac{\mathrm{C}_{1}+\mathrm{C}_{2} \cdot \mathrm{Sh}_{\mathrm{A}}}{100-\mathrm{Sh}_{\mathrm{A}}}\left[\frac{\mathrm{N}}{\mathrm{mm}^{2}}\right] .
$$

where

E: Elastic modulus of the embedding compound

$\mu$ : Poisson-coefficient of the embedding compound

$\mathrm{R}$ : radius of durometer

$\mathrm{C}_{1}, \mathrm{C}_{2}$ : examination constants $[\mathrm{N}]$

$\mathrm{C}_{3}$ : examination constant $[\mathrm{mm}]$.

The values of the constants are summarized in Table 1. according to the examination standard.

Table 1.: The values of the examination constants according to DIN EN ISO 868

\begin{tabular}{|c|c|}
\hline Parameter & Value \\
\hline R & $0.395[\mathrm{~mm}]$ \\
\hline C1 & $0.549[\mathrm{~N}]$ \\
\hline C2 & $0.07516[\mathrm{~N}]$ \\
\hline C3 & $0.025[\mathrm{~mm}]$ \\
\hline
\end{tabular}

The formula above could be used in practice extremely well if it didn't include two unknown coefficients. This problem can be solved with a simplification if $\mu$ with 0.5 is substituted. This approach is generally accepted in the engineering practice in case of elastomers. Based on the literature this formula can be applied for hardness values between 30 and $95 \mathrm{Sh}_{\mathrm{A}}$.

The author applied the method on three embedding compounds available in commercial traffic. He named them $\mathrm{A}, \mathrm{B}$ and $\mathrm{C}$ compounds, making it possible to introduce the method independent from the manufacturer and the product. Making the calculations the received results there are in Table 2. (supposing $\mu=0.5$ ).

Table 2.: Values of the producing and the calculated elastic modulus

\begin{tabular}{|c|c|c|c|}
\hline Material & $\boldsymbol{S h}_{\boldsymbol{A} \text { mean }}$ & $\boldsymbol{E}_{\text {producing }}[\mathbf{N} / \mathbf{m m}$ 2] & $\boldsymbol{E}_{\text {calculated }}$ [N/mm2] \\
\hline „A" & 40 & 2.20 & 2.25 \\
\hline „B” & 58 & 4.20 & 4.44 \\
\hline ,C" & 65 & 5.70 & 5.90 \\
\hline
\end{tabular}


The results well approach the results given by the manufacturer in spite of the simplification, the difference of the method is only $5.7 \%$ even in the worst case.

\subsection{Determining the Poisson-coefficient}

To make the model produce appropriate outgoing results (vertical stiffness), it is necessary that the Poisson-coefficient should be close to reality. FEM models are extremely sensitive to the changes of the Poisson-coefficient so $\mu=0,5$ approach can't be used, because a stiffer system should be modelled than reasonable. Accepting the elastic module determined earlier, the coefficient can be determined with iteration based on other details.

In the following two chapters the author will only deal with elastic characteristics. The result of the modelling will be compared with the results of two laboratory examinations in order to describe the success of FEM modelling and its usability in the optimization process.

\section{Numerical modelling of laboratory examinations}

\subsection{Examination of structure formed with Ts52 rail}

Dr. László Kazinczy announces the examination results of a structure formed with Ts52 rail, VA-70 embedding compound in his presentation [9] in Szeged on 10, April, 2013. The author determined the typical parameters of the embedding compound $(\mathrm{E}, \mu)$ with the method shown in the previous chapter and based on the stated geometry (Figure 1.). The modelled structure is shown in Figure 2..

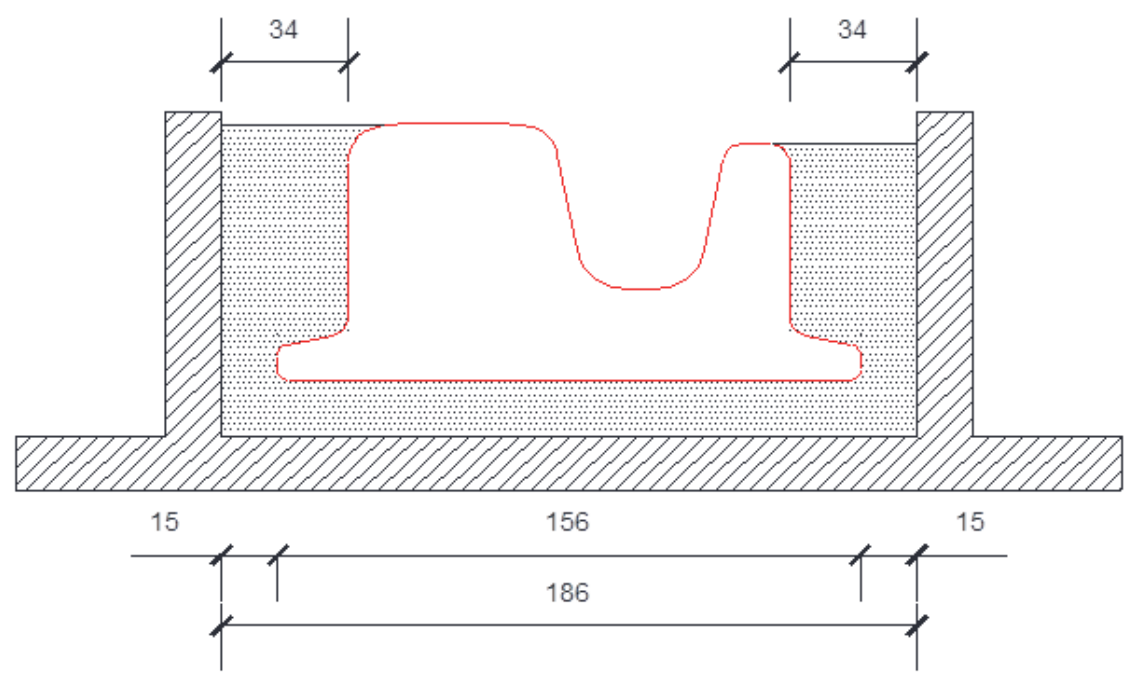


Figure 1.: The geometry published by Dr. László Kazinczy (the sizes are counted in $\mathrm{mm}$ )

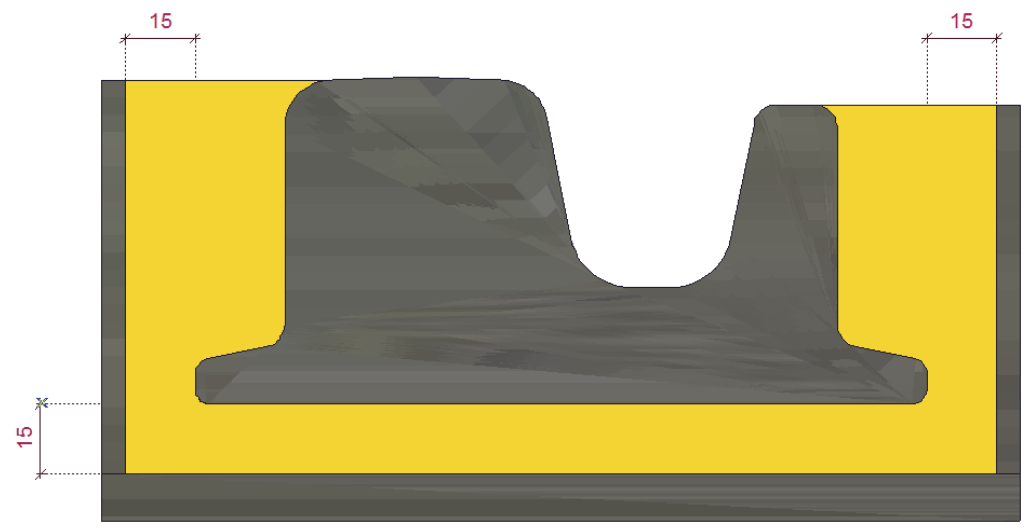

Figure 2.: The modelled rail channel (Ts52) (the sizes are counted in $\mathrm{mm}$ )

Two models are needed to prepare for examinations. A $10-\mathrm{mm}$-thick plain strain model was applied in the condition of planar deformation to determine the static embedding coefficient and a 250-mm-long plate model was used to examine the pushing.

To determine the embedding coefficient the plain strain model with $1[\mathrm{kN}]$ vertical force was loaded. The results of running are shown in Figure $3 .$.

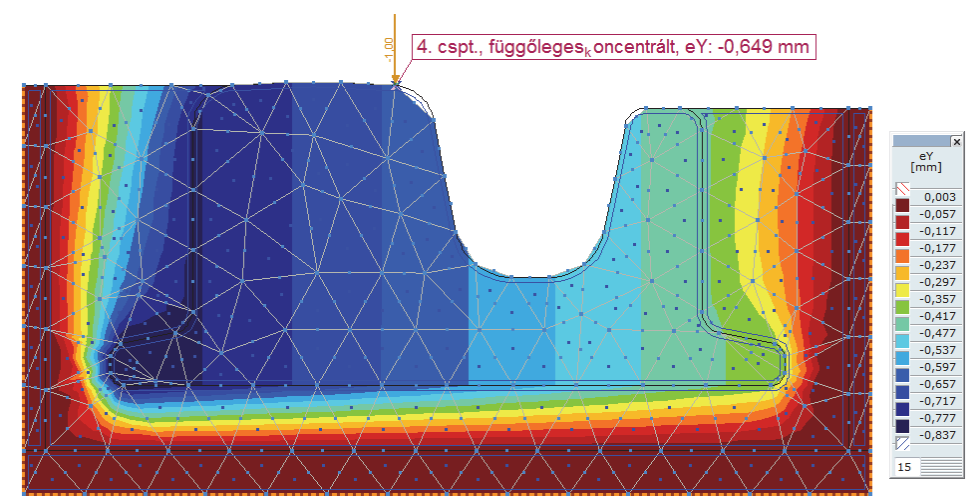

Figure 3.: Vertical deformation in the plain strain model

Based on the received results the embedding coefficient can be calculated with the following formula: 


$$
\mathrm{C}=\frac{1000[\mathrm{~N}]}{0.649[\mathrm{~mm}] \times 10[\mathrm{~mm}] \times 156[\mathrm{~mm}]}=0.99\left[\frac{\mathrm{N}}{\mathrm{mm}^{3}}\right]
$$

The following table summarizes the results that Dr. Kazinczy László and I received:

Table 3.: The embedding coefficient value in the examined cases (Ts52) (I.)

\begin{tabular}{|c|c|}
\hline Case & Embedding coefficient [N/mm3] \\
\hline $250 \mathrm{~mm}$ - Test specimen - Dr. Kazinczy & 1.18 \\
\hline $900 \mathrm{~mm}$ - Test specimen - Dr. Kazinczy & 0.91 \\
\hline Mean value- Dr. Kazinczy & $1.05(100.0 \%)$ \\
\hline FEM model (10 millimeter) & $0.99(94.3 \%)$ \\
\hline
\end{tabular}

The calculation was repeated in order to get a picture of the behaviour of the model. In these cases 1 [kN] force is placed on the 250 and the $900-\mathrm{mm}$-long plain strain model. The received results are summarized in Table 4 ..

Table 4.: The embedding coefficient value in the examined cases (Ts52) (I.)

\begin{tabular}{|c|c|}
\hline Case & Embedding coefficient [N/mm3] \\
\hline Mean value - Dr. Kazinczy & $1.05(100.0 \%)$ \\
\hline FEM model $(250 \mathrm{~mm})$ & $0.99(94.3 \%)$ \\
\hline FEM model $(900 \mathrm{~mm})$ & $0.89(84.8 \%)$ \\
\hline
\end{tabular}

Based on the numerical examinations carried out it can be seen that the size of the model has an effect on the received results. In the 10-250-mm-long scope the difference is $5.7 \%$, whereas this difference is $15.2 \%$ in case of $900 \mathrm{~mm}$. It has to be noted that if measured values with the average are compared, the difference is $12.4 \%$ in case of the $250-\mathrm{mm}$ trial body, and it is $13.4 \%$ with the $900-\mathrm{mm}$ one. The results above show that the behaviour of the applied model is very similar to the behaviour of the real structure.

After determining the embedding coefficient the longitudinal resistance were examined on the $250-\mathrm{mm}$-long plate model. $96.18(\mathrm{kN})$ force was put on the model and the extent of the occurring displacement was examined. The results of the running are described in Figure 4.. 


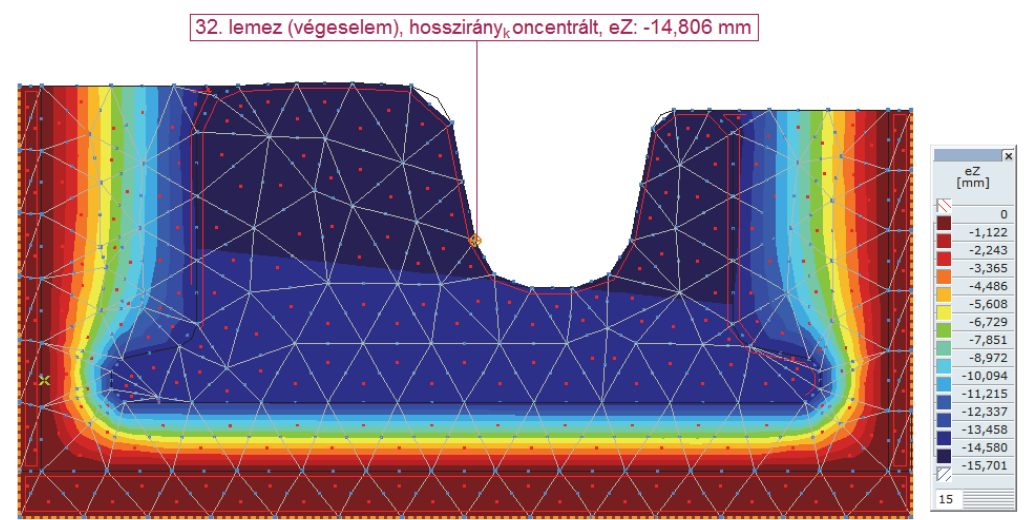

Figure 4.: Longitudinal deformation on the plate model (Ts52)

The results that Dr. László Kazinczy and the author received are summarized in Tables 5. and 6..

Table 5... The values of longitudinal displacement in the examined cases (Ts52)

\begin{tabular}{|c|c|}
\hline Case & Longitudinal displacement [mm] \\
\hline 250 mm- Test specimen - Dr. Kazinczy & $16.000(100.0 \%)$ \\
\hline FEM model & $14.806(92.6 \%)$ \\
\hline
\end{tabular}

Table 6.: The value of the longitudinal spring constant in the examined cases. (Ts52)

\begin{tabular}{|c|c|}
\hline Case & Longitudinal spring constant $[\mathbf{k N} / \mathbf{m m}]$ \\
\hline $250 \mathrm{~mm}$ - Test specimen - Dr. Kazinczy & $6.01(100.0 \%)$ \\
\hline FEM model & $6.49(107.9 \%)$ \\
\hline
\end{tabular}

Based on the results above it can be seen that the results received by FEM modelling adequately approach the results of real laboratory measurements. (There has not been a bigger difference than $8 \%$ in the examined case), so they make the appropriate start-up base for the optimization process. More research is needed to select the right size of the model and to determine the exact behaviour of the embedding compounds with different stresses.

\subsection{Examination of a structure with 35GPB rail}

Dr. Ferenc Horvát and Dr. György Németh referred to the examination report No R3830 of the Edilon company in their certification [10] published on 26 April 2004. During the examinations they applied a test specimen formed with $35 \mathrm{GPB}$ rail and VA$60 \mathrm{~N}$ compound. 
The width of the rail channel was $170 \mathrm{~mm}$ and its height was $97 \mathrm{~mm}$. Under the rail foot the thickness of the pouring was $15 \mathrm{~mm}$. The length of the trial body was $300 \mathrm{~mm}$. The prepared model is shown in the following Figure 5.

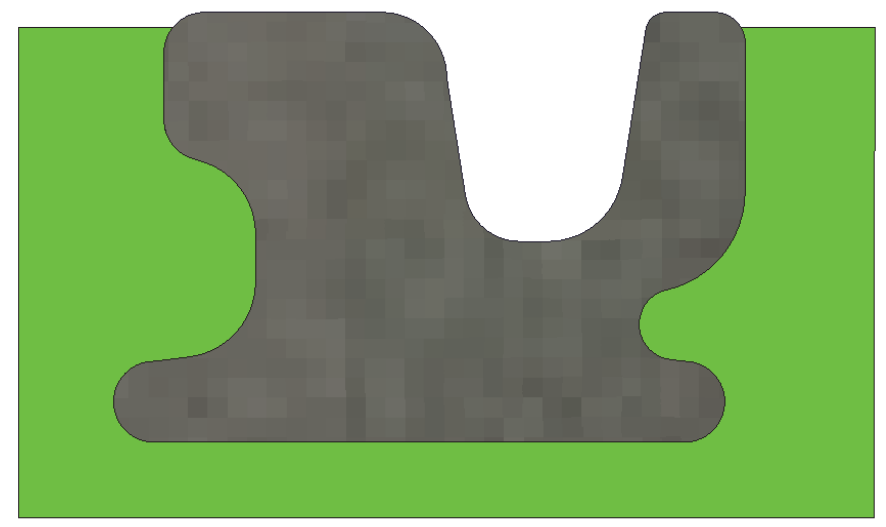

Figure 5.: The modelled rail channel (35GPB)

When examining the vertical static spring constant a 300 -mm-thick plain strain condition model was used, which was loaded with $22.5(\mathrm{kN})$ vertical force. The displacements of the model are shown in Figure 6..

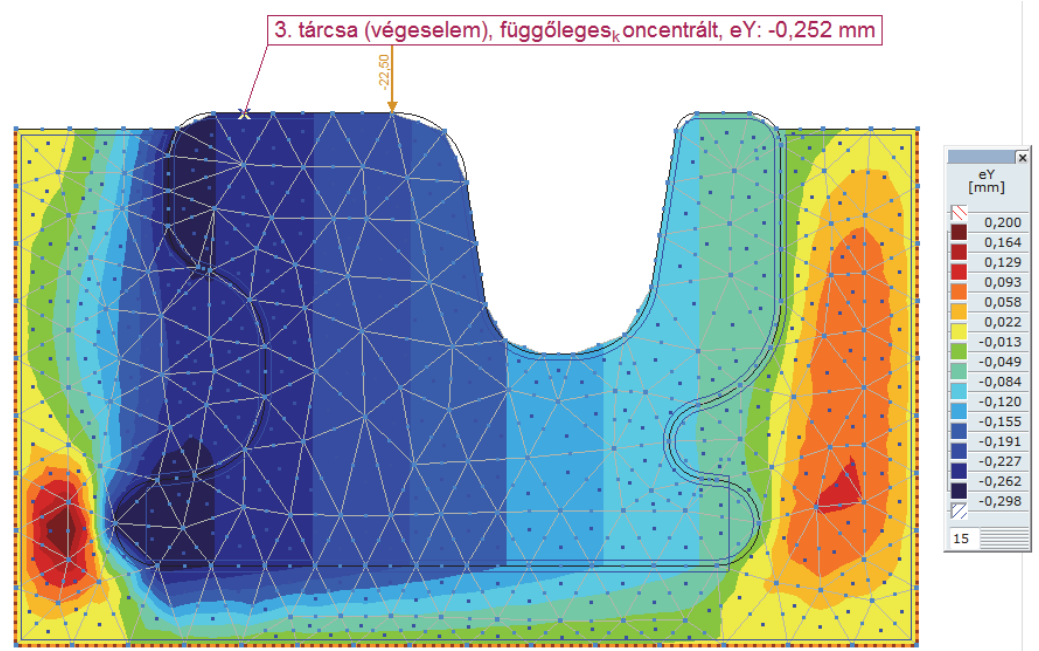

Figure 6: Vertical deformation of the model (35GPB)

The received results are summarized in Table $7 .$. 
Table 7.: The value of vertical displacement in the examined cases (35GPB)

\begin{tabular}{|c|c|}
\hline Case & Vertical displacement [mm] \\
\hline Report - R3830 & $0.290(100.0 \%)$ \\
\hline FEM model & $0.252(86.9 \%)$ \\
\hline
\end{tabular}

Based on the results the value of the vertical static spring constant for a $300-\mathrm{mm}$ test specimen was determined. The results received are summarized in Table 8 ..

$$
\begin{aligned}
& \mathrm{k}_{\text {stat }}=\frac{22.5[\mathrm{kN}]}{0.290[\mathrm{~mm}]}=77.6[\mathrm{kN} / \mathrm{mm}] \\
& \mathrm{k}_{\text {stat }}=\frac{22.5[\mathrm{kN}]}{0.252[\mathrm{~mm}]}=89.3[\mathrm{kN} / \mathrm{mm}]
\end{aligned}
$$

Table 8.: The value of the vertical static spring constant in the examined cases (35GPB)

\begin{tabular}{|c|c|}
\hline Case & Static vertical spring constant $\mathbf{~} \mathbf{k} / \mathbf{m m}]$ \\
\hline Report - R3830 & $77.6(100.0 \%)$ \\
\hline FEM model & $89.3(115.1 \%)$ \\
\hline
\end{tabular}

In the examined case the difference from the measured result was $15.1 \%$. The examinations with the Ts52 rail have shown that the differences of the 2 measurements from the average are $12.4 \%$ and $13.4 \%$ in real cases. Based on this it can be stated that the behaviour of the applied model well approaches the behaviour of the real structure.

Finally the extent of resistance against longitudinal force on a $300-\mathrm{mm}$-long plate model was examined. The occurring displacement is shown in, Figure 7., the results received are summarized in Table 9. and 10. . 


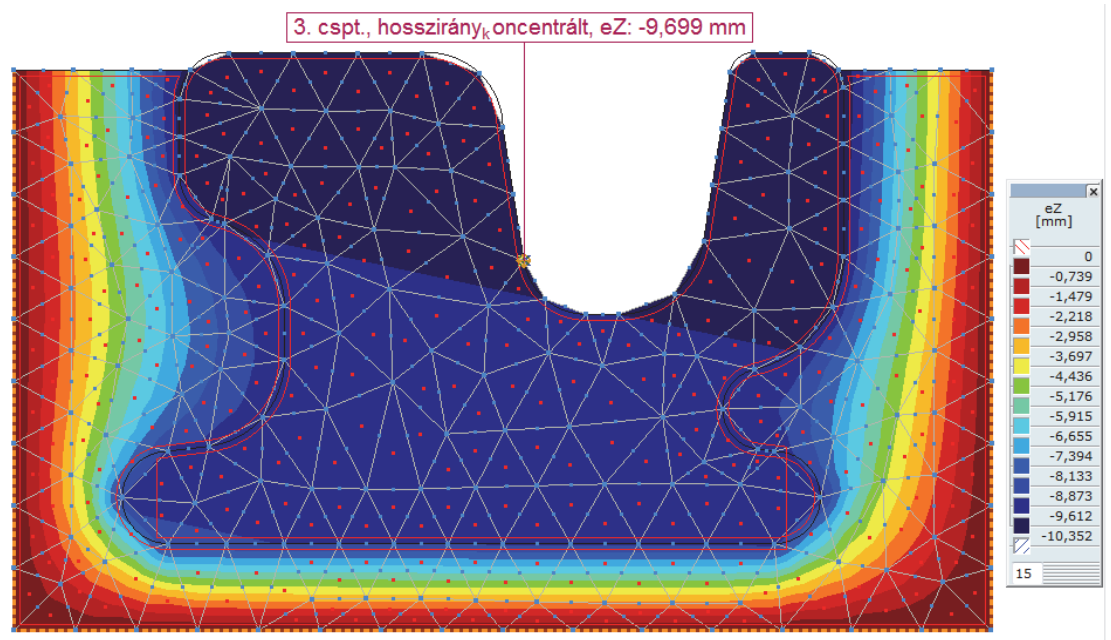

Figure 7.: Longitudinal deformation on the plate model (35GPB)

Table 9.. Longitudinal displacement in the examined cases (35GPB)

\begin{tabular}{|c|c|}
\hline Case & Longitudinal displacement [mm] \\
\hline Report - R3830 & $10.000(100.0 \%)$ \\
\hline FEM model & $9.699(96.9 \%)$ \\
\hline
\end{tabular}

Table 10.: The value of the longitudinal spring constant in the examined cases

\begin{tabular}{|c|c|}
\hline Case & Longitudinal spring constant $[\mathbf{k N} / \mathbf{m m}]$ \\
\hline Report - R3830 & $5.10(100.0 \%)$ \\
\hline FEM model & $5.16(101.2 \%)$ \\
\hline
\end{tabular}

Based on the results above it can be seen that the results of FEM modelling well approach the results of real laboratory measurements. (The greatest difference was about $15 \%$ in the examined case), so they make an adequate initial base for optimization. More research is necessary to select the appropriate size of the model and determine the exact behaviour of the embedding compounds with different stresses.

\section{Further research possibilities}

FEM modelling shown in this article offers good opportunity for investigation and design of railway superstructure with embedded rails. It is an important question to accurate design of transition zones. In this case FEM modelling is not enough, because spring constants related to ballasted tracks can't be determined. In case of modelling ballasted tracks the DEM simulation is able to be applied $[11,12,13]$, in which railway ballast is modelled by discrete element particles (balls and clumps). Layer structures can 
be optimised by using results that come from DEM models. This is very important because track geometry faults can be avoided. If track faults aren't eliminated speed restrictions have to be used that cause additional traction energy and time consumption of railway vehicles in operation $[14,15]$. These energy and time consumption values can be calculated according to the allowed speed and type of railway vehicles, as well as through-rolled tons.

\section{Summary}

In this article the author presented a method that is suitable for modelling the elastic behaviour of embedded rails with adequate accuracy. To show the success of the modelling the author compared the results of two laboratory examinations with the results of FEM model. It has been proven that the results given by the models provide a good initial base for the optimization of embedded rail structures. Only a part of the necessary details are available for optimization so more research is needed to determine the adequate weight coefficients to find out about optimization factors on the basis of the contractor's and the operator's details.

\section{References}

[1] Lehner S: Kontinuierlich eingegossene Schiene, TemperaturverteilungVerbundwirkung_Brücken

[2] Major Z: Rugalmas ágyazású kiöntött csatornás vasúti felépítmény (1. rész): A síncsatorna kiöntőanyag jellemzőinek meghatározása, Sínek Világa, Vol. 55, No. 6, pp. 10-12, 2013

[3] Kulcsár N, Major Z: Rugalmas ágyazású kiöntött csatornás vasúti felépítmény (2. rész): Rugalmas síncsatorna-kiöntések numerikus modellezése, Sínek Világa, Vol. 56, No. 1, pp. 22-26, 2014

[4] Markine VL, de Man AP, Jovanovic S, Esveld C: Optimum design of embedded rail structure of high-speed lines, CD Proceedings of the International Conference, Railway Engineering 2000, London UK, July 2000

[5] Esveld C: Modern Railway Track - Second Edition, MRT-Productions, Zaltbommel, 2001

[6] Ludvigh E: Elastic behaviour of continuously embedded rail system, Periodica Polytechnica, Vol. 46, No. 1, pp. 103-114, 2002

[7] Kunz J, Studer M: Determining the Modulus of Elasticity in Compression via the Shore A Hardness, Kunststoffe international, No. 6, 2006

[8] DIN EN ISO 868: Kunststoffe und Hartgummi- Bestimmung der Härte mit einem Durometer (Shore- Härte)

[9] Kazinczy L: Sínszálak ágyazásának és rögzítésének körülményei a burkolt közúti vasúti vágányoknál - presentation, Szeged, 10 April 2013.

[10] Horvát F, Németh Gy: Hazai Megfelelőség Igazolás - 35GPB (35LPG) r. sínekkel kialakított, Edilon típusú kiöntött síncsatornás közúti vasúti vágány kísérleti szakaszának építésére, Győr, 26 April 2004.

[11] Fischer Sz, Horvát F: A georács erősítésü vasúti zúzottkő ágyazat diszkrét elemes modellezési lehetőségei, Közlekedésépítési Szemle, Vol. 60, No. 8, pp. 20-29, 2010 
[12] Fischer Sz, Horvát F: Investigation of the reinforcement and stabilisation effect of geogrid layers under railway ballast, Slovak Journal of Civil Engineering, Vol. 19, No. 3, pp. 22-30, 2011

DOI: $10.2478 / \mathrm{v} 10189-011-0015-\mathrm{y}$

[13] Fischer Sz, Horvát F: Superstructure stabilization of ballast bedded railway tracks with geogrids, Hungarian Journal of Industrial Chemistry, Vol. 39, No. 1, pp. 101106,2011

[14] Fischer Sz: Traction Energy Consumption of Electric Locomotives and Electric Multiple Units at Speed Restrictions, Acta Technica Jaurinensis, Vol. 8, No. 3, pp. 240-256, 2015

DOI: 10.14513/actatechjaur.v8.n3.384

[15] Fischer Sz: Lassújel miatti többlet-költségek és a megszüntetés költségeinek összehasonlítása, Sínek Világa, No. 5, pp. 21-29, 2011 